\title{
Women Objectification in Carl's JR TV Advertisements
}

\author{
Ivi Meiccel Vidia ${ }^{I)}$, Pratiwi Retnaningdyah ${ }^{2)}$ \\ ${ }^{1}$ Universitas Negeri Surabaya, Surabaya, Indonesia \\ ivi.17020154050@mhs.unesa.ac.id \\ ${ }^{2}$ Universitas Negeri Surabaya, Surabaya, Indonesia \\ pratiwiretnaningdyah@unesa.ac.id \\ Received:31 ${ }^{\text {st }}$ August 2021| Revised:16 ${ }^{\text {th }}$ September 2021| Accepted: $20^{\text {th }}$ November 2021 \\ Email Correspondence: ivi.17020154050@mhs.unesa.ac.id
}

\begin{abstract}
The purpose of this paper is to explore the Indonesian youth audiences' reaction to objectification in Carl's Jr American TV ads. In the ads, white women become the focus of the ads and represent the product as a way to promote Carl's Jr. The study aims at examining the representation of women in the ads from the audiences' eyes and the audiences' reaction to the objectification. Moreover, Frederickson \& Robert's Objectification theory serves as the theoretical framework upon which women objectification is examined within the feminism and cultural contexts. The result of this study reveals that the audiences think the white women in the ads are being sexualized and objectified as the product that is being promoted. Furthermore, the audiences also think the women's existences are reduced as a commodity to lure in male customers and increase the products' sales. Some of the audiences think there is nothing wrong with the ads, some are neutral with it, while the rest wants the ads to be stopped.
\end{abstract}

Keywords: women objectification, audience reception

\section{INTRODUCTION}

The representation of women as sexual objects is not only seen in real life, but it has been found in various media, including ads. From the ads that we watched, most of its content is absorbed by our unconscious mind, thus getting exposed to those kinds of ads will influence our mind to think women as an object (Kilbourne, 2010). As this paper will demonstrate, the writer argues that youth audiences perceive Carl's Jr ads as sexualizing women and objectify their bodies as the representation of the food. Moreover, youth audiences demonstrate various responses to the objectification, some of them got dominant reading, negotiated reading, and the rest oppositional reading. Those are borrowed from Hall's theory of reception. Although the ads are American TV ads, a fair amount of Indonesian middle to upper class have access to TV

Online at https://journal.universitasbumigora.ac.id/index.php/humanitatis/

DOI : https://doi.org/10.30812/humanitatis.v8i1.1427 
cables and therefore, they are exposed to these ads. It is important to raise awareness of this issue, especially among English-speaking Indonesian youngsters.

In this context, Frederickson \& Roberts offers grounds for understanding the characteristics of women objectification on white women (Fredrickson \& Roberts, 1997). In her study, Frederickson (1997) mentioned that the objectification of women in mass media is increasing rapidly to the point that it becomes unavoidable. In this study, Frederickson's objectification will be employed to analyze the audiences' reaction in which they argue that the women in ads are sexualized and objectified as the product to grab viewers' interest and increase Carl's Jr sales. Furthermore, Hall's audience reception theory (1973) will be applied to discover the youth audiences' reception in feminism and cultural context. Using Frederickson's objectification theory and Hall's audience reception theory, this article presents two questions that must be tackled: How is the representation of women in the audiences' eyes? How is women objectification in the ads received by Indonesian youth audiences?

This study is created with an argument that many ads objectified women's bodies to sell products and women in real life are negatively affected by the effect of objectification in the media. Thus, hopefully after reading this study, many people will be more aware of this issue and there will be steps taken to solve this problem.

Objectification can be defined as evaluating white women based on their faces and body and forget their value as equal human beings. Instead, those women are treated as an object to be looked at and pleasure men's needs (Fredrickson \& Roberts, 1997). The issue of women objectification is not only appeared in ads, there have been several studies that analyzed women objectification in social media (Davis, 2018), women objectification in Music Videos (Aubrey \& Frisby, 2011), and women objectification in real life through Halloween costumes (Lennon, Zheng, \& Fatnassi, 2016). All of these studies have shown that women are objectified way more often than men and objectification has negative side effects for women especially the younger ones.

Davis (2018), in her article titled "Objectification, Sexualization, and Misrepresentation: Social Media and the College Experience," studies two Instagram pages that post pictures of drunk female college students at parties. Those pictures are taken unknowingly from the women

Online at https://journal.universitasbumigora.ac.id/index.php/humanitatis/

DOI : https://doi.org/10.30812/humanitatis.v8i1.1427 
and they are often depicted as submissive sex objects to please men. The writer then analyzes the comment section on that Instagram page, which is left by men, and the writer concludes those women are objectified gazed at as sex objects by the men who saw and follow the Instagram accounts. Meanwhile, Aubrey (2011), in her article, "Sexual Objectification in Music Videos: A Content Analysis Comparing Gender and Genre," compares the gender differences of objectification in different genres of music (R\&B/Hip-Hop, Pop, and country). She finds out that female artists are more sexually objectified than their male counterparts. Additionally, female artists are judged harsher in terms of their physical appearances and attractiveness than male artists. In contrast to that, Lennon (2016), in her article, “Women's Revealing Halloween Costumes: Other-objectification and Sexualization," decides to investigate the differentiation between men's and women's Halloween costumes to find out whether women who wear revealing costumes will be objectified or not. For this study, the writer firstly chooses Halloween costume pairs from 15 websites and sorts them down into 20 costumes. And then, the writer conducts an online survey to find out how other people perceive women who wore revealing costumes. The results are women's Halloween costumes are indeed more revealing than men's and women who wore revealing Halloween clothes were rated lower of positive personality traits like loyal, considerate, and sincere. Besides that, those women were rated as more feminine than the ones who were less revealing clothes.

Jensen(1991) in Schrøder(2019) defines audience reception as the semiotic process in which the audiences decode the message that has been encoded by the producer and try to understand the hidden message based on their environment and background. Thus, audience reception is also called as encoding/decoding theory due to its process. According to Hall (1973), there are three types of audiences' position after decoding the message and those are; dominant reading, negotiated reading, and oppositional reading. When someone encodes the message in the media the way the producer intended it to be and agrees with the producers, then he got dominant reading. Meanwhile, in negotiated reading, a person understands the producer's view but is unwilling to accept the message. And lastly, if someone gets oppositional reading, he cannot adapt to the producer's views and reject them completely. There are numerous studies using audience reception theory but for the sake of this study, only three will be briefly 
discussed. Those studies are Analysis Transnational audience reception as a theater of struggle: young Filipino women's reception of Korean television dramas (Espiritu, 2011), GAZING UPON THE KINGDOM: An Audience Reception Analysis of a Televised Travelogue (Yoo \& Buzinde, 2012), and Audience Readings and Meaning Negotiation in the Film Viewing Space: An Ethnographic Study of Nollywood's Viewing Center Audiences (Elinwa, 2020).

Espiritu (2011) in her study examines young women's reception of Korean television dramas from the cultural imperialism perspective both in the international arena and in the incorporation of the global capitalist culture in selected Korean television dramas. The writer of this study uses Stuart Hall's encoding/decoding theory and Anthony Giddens' thoughts on selfidentity and modernity to gain the result. After interviewing the correspondences, the writer finds out that Filipino women can relate to the hardworking female protagonist in Korean drama and prefer to watch Korean drama due to its realistic aspect. But they think the rich boy-poor girl theme is cliché and unrealistic. In conclusion, Korean drama is popular with Filipino women due to its realistic storyline and relatable heroine. Meanwhile, Yoo (2012) examines a television program No Reservations that featured on Saudi Arabia and conducts surveys from two groups: a group full of American participants and another one full of Saudi Arabian participants. The result revealed that the American participants realized that Saudi Arabia is not as bad as how the media portrayed them, and the Saudi Arabian participants are happy with the program because it demonstrates their cultures and lifestyle correctly. The audiences think that the television program is doing a good job in fighting the negative stereotype that the news gave to Saudi Arabia. On the other hand, Elinwa (2020) conduct a fascinating study that aims to determine how social experiences influence audience perception of the meaning behind the film. The writer uses active participant observation and unstructured interviews to obtain the desired result. The results are that each people have different interpretations of the film according to their experiences and daily lives; but they agree that watching a film is a form of solidarity and part of social interaction, not an individual activity.

Various studies have been conducted on women objectification and audience reception, yet none have examined Carl's Jr advertisements. Therefore, this study has a purpose to unravel the

Online at https://journal.universitasbumigora.ac.id/index.php/humanitatis/

DOI : https://doi.org/10.30812/humanitatis.v8i1.1427 
portrayal of white women objectification in the ads by analyzing the answers from Indonesian youth audiences.

\section{RESEARCH METHOD}

Method This study is a reception analysis of the American Carl's Jr TV advertisements among youth audiences in Indonesia. The writer conducted an audience reception analysis of five selected TV ads to reveal white women's objectification happening in the ads. Those ads are: Cranberry Apple Walnut Chicken Salad (2010), The Southwest Patty Melt (2012), Memphis BBQ (2012), The All-Natural Burger (2015), Bacon 3-Way Burger (2016). Next, the writer organized a questionnaire to see how the younger generation in Indonesia reacts to the ads. The audiences are Indonesian people within the age range of 16-26 with different socio-cultural backgrounds regardless of gender. The result of their reaction will be divided into three: (1) Dominant readings, (2) Negotiated readings, and (3) Oppositional readings. These three reactions are taken from Stuart Hall's reception theory, those people will either understand the producer's hidden message and accept it as it is, understand but does not agree with it, or do not want to try to understand at all (Hall, 1973).

The questionnaire was made in Google Form and it was shared with the participants from March 11th - March 15th, 2021. The writer first asks the participants' ages and genders, and then the videos of the ads are attached to the questionnaire as well. After that, the participants are given these questions below:

1. After watching those five ads above, what is your opinion about those ads? How do the ads make you feel?

2. In your opinion, what is the producers' intention when he creates those ads?

3. Do you think that those kinds of ads grab the viewers' interest? Please explain your reason.

4. Do you think that those kinds of ads increase Carl's Jr's popularity? Please explain your reason.

5. Do you think that the women's appearances (in term of face and body wise) in the ads increases Carl's Jr sales? Please explain your reason. 
6. In your opinion, should Carl's Jr continue to produce those kinds of ads? And what is your reason?

7. If Carl's Jr creates similar ads for Indonesian audiences, do you think it will be acceptable? Why or why not?

The writer then analyzes the answers of the participants using Frederickson \& Barbara's objectification theory and Hall's audience reception theory to see how the women are represented in the ads and how the participants react to the ads.

\section{FINDINGS AND DISCUSSION}

\subsection{In Representation of women in the audiences' eyes}

In the audiences' eyes, the women on Carl's Jr ads are being sexualized and turned into the burger in order to promote Carl's Jr product and increase their sales. Instead of using the actual product which is burgers, women are objectified to fulfill viewers' pleasure.

\subsubsection{Women as being sexualized}

For some audiences, the producers are trying to sell their product by showing unnecessary body parts of women and they feel uncomfortable with the ads vulgarity. This is in line with what Vance said in her journal about the characteristic of objectification which is, during objectification, the woman in the ads is given sensual clothes and told to pose seductively. In addition to that, the camera will focus more on her body and less on her face (Vance, Sutter, Perrin, \& Heesacker, 2015). The audiences can see that and they give their comments regarding the women's bodies and actions. One of the examples is what Haya and Laily said:

I think those ads were too "sexual" since the ads expose women's sexiness whether it is the body or the gesture and it attracts more eyes to stare at the ads, especially men. But honestly, men will more focus on women's physical appearance than on the products. Those ads make me feel uncomfortable in some ways knowing that there are lots of boobs and hips and licks and creamy liquid. Haya

Honestly, I feel those ads are cringeworthy. All of them exploit women's figures in a vulgar way. I mean, I don't see any relation between eating food in a bed and sexy girl in pajamas, or in another video, I see some girls who wear their bikini cook enthusiastically. The question is, why those food ads portray a sexy woman. If the creator wants to highlight the food taste. I think they don't need to show how vulgar the women projection in the video. It is indicated that those ads target

Online at https://journal.universitasbumigora.ac.id/index.php/humanitatis/

DOI : https://doi.org/10.30812/humanitatis.v8i1.1427 
men as their market. Well, I don't think highlight vulgarity is a proper act to advertise the product itself. - Laily

The two women audiences critic the producers' choice to sexualize women in the ads. They think the ads are too much to be broadcasted on television and it does not match with the product at all. Besides, the ads show too much cleavage and hips. This, according to Aubrey (2011), is another sign of objectification. If women's bodies are gazed at for a long period by men and those body parts are usually the ones that are associated with sexual activity such as cleavage, buttock, and pelvis, then it is without doubt objectification (Aubrey \& Frisby, 2011). Haya and Laily do acknowledge the women in the ads are being sexualized and they notice the characteristics of the objectification. In addition to that, Anggie's argument when asked about the producers' intention is:

They try to sell foods by promoting women's lips, boobs, slim bodies, and ass (+ tendency to lesbian or threesomes among women). I feel disgusted, but it seems that this concept has become their trademark. - Anggie

Anggie specifically talks about the Memphis BBQ (2012) and Bacon 3-Way Burger (2016) ads because those two ads suggest a same-sex relationship between women with their interaction. As (Szymanski, Moffitt, \& Carr, 2011) explained, a lesbian relationship is heavily sexualized in the media to satisfy men's sexual desire which is getting in sexual activity with two or more women at the same time. Proving that the ambiguous interaction between the women is to pleasure the male viewers.

\subsubsection{Women as objects}

The women on the ads represent the product that Carl's Jr trying to sell. By using the women, Carl's Jr is trying to demonstrate how hot and fresh their food is. Some of the youth audiences also take notice on this phenomenon as some of them comments on this particular objectification.

Those ads must not be continued because they sell the models' bodies and do not deserve to be aired. Carl's Jr seems to sell the women, not the product. It can be seen in some ads that compare the ads to the product. - Wido

It is not a reach to say that Carl's Jr selling the women's body appearances to show the messages about different kinds of burgers in the ads. For example, in the All Natural Burger ad, the woman appears to be naked. This is to showcase how the burger is

Online at https://journal.universitasbumigora.ac.id/index.php/humanitatis/

DOI : https://doi.org/10.30812/humanitatis.v8i1.1427 
hundred percent natural without hiding anything and anyone can feel the freshness. Belinda

People might be wondering how hot the jalapeno is, how fresh the salad is, and how crisp the bacon is and that's why the producers objectify the women as the product. Those curious customers might boost Carl's Jr sales in a certain period but after they taste the product they can decide what suits them well. - Rio

Kant (as cited in Rector, 2014) stated that having dignity is what makes a human different from animals and objects. Meanwhile, during the objectification in the ads, the women are degraded into objects as their dignities are ignored by the producers. It is clear that the women are living beings and not just a prized item to be gazed at, yet their existences are reduced to those of inanimate objects to highlight Carl's Jr's products.

\subsection{Audiences' reaction to women Objectification}

After gathering answers from 44 audiences within the age range of 16-26, the reception from those audiences will be divided into three categories which are: dominant reading, negotiated reading, and oppositional reading.

\subsubsection{Dominant Reading}

Out of 44 answers, 7 people understand the underlying message from the producers and agree with the producers' views. From the 7 opinions, there are three main points why they support the producers. First, because the producers did a good job catching male customers with sexy women to promote the product, another is suggesting for Carl's Jr to create ads with male models, and the last is seeing the ads through the female gaze.

a. Sexy images for marketing

In the dominant reading section, two people think that the women are chosen to appear in the ads according to their physical appearances. The producers intentionally chose pretty women with the ideal body to satisfy male customers. Based on western culture, the ideal women's body must be thin and skinny, but also have big breasts (Grogan, 1999). All the women in the ads have the same body type which is tall, slim, but curvy on certain areas such as the breasts and hips. Here are the audiences' answers when asked 'In your opinion, what is the producers' intention when he create those ads?"

Showing the special ingredients in the food, by using women's bodies with sexy images as the eye candy that can increase the selling point. - Niki

Online at https://journal.universitasbumigora.ac.id/index.php/humanitatis/

DOI : https://doi.org/10.30812/humanitatis.v8i1.1427 
As a man, those ads make me lose my focus on the product itself. I only focused on the ads lol, rather than the product. These ads are good to keep male customers' intention. Farhan

Niki further describes the ads will attract male viewers and since Carl's Jr is popular worldwide, the ads must have been a successful attempt to attract customers. She ends her argument by saying that the sensual and ambiguous ads have become the trademark for Carl's Jr, thus they should continue to produce those ads. Meanwhile, Farhan states that the women's gestures and appearances in the ads are focused on certain markets, which are male customers. Thus, it is alright to continue as it has been proven to attract lots of male customers.

b. Proposing male models to attract female customers

One of the audiences, Alan, comments that the ads are quite attractive for men but not so much for women. When asked whether Carl's Jr should continue producing those kinds of ads or not, he says:

For a "sensational" factor, yes, they should, because that might help Carl's Jr to gain more popularity. But if the company wants to get more consumers, the company might use male models so the products not only attract male consumers but also female consumers. - Alan

He gives creative suggestions for Carl's Jr and proposes them to use the female gaze not only the male gaze as the customers vary between the two genders. Overall, Alan thinks that those kinds of ads are creative and out-of-the-box, so they should be continued.

\section{c. Female Gaze}

Unlike the male gaze which focused on objectifying women, the female gaze focuses on women's visual and expression, it demonstrates people as human beings (Stewart, 2015). Some of the women who answer the questionnaire show their opinion on the ads not from the way the models are being sexualized but rather from their perspective as fellow women. For instance, Lina and Erika said:

American culture defines pretty women as slim, have big boobs, and pretty face. By using those sexy models, Carl's Jr not only wants to attract men as their market but also show to the girls, if many pretty women still can eat their "fast food" without gaining weight. Moreover, they also talk if their product is made from natural things. It is really nonsense, as far as I know, fast food has a huge number of calories. Here, by showing

Online at https://journal.universitasbumigora.ac.id/index.php/humanitatis/

DOI : https://doi.org/10.30812/humanitatis.v8i1.1427 
those figures, he wants to deceive the girl about the calorie. Yeah, I think, this strategy will increase their marketing. - Lina

Just like the women figures on the ads, the sexy burger will never make you fat. - Erika

These two women take into a calculation that the women viewers might admire the women's bodies on ads and get persuaded to buy the burger. They did not think these kinds of ads will only work to grab male viewers' interest, but also women viewers. And that is why they think the ads are interesting and should be continued.

\subsubsection{Negotiated Reading}

There are 13 women and 3 men who are in the negotiated reading position. All of those people get the clear message of what the producers intend to send to the audiences but that does not mean that they agree with the producers' view. Additionally, 7 out of 16 of them think it is not a big problem for Carl's Jr to keep on producing those kinds of ads whereas the rest 9 people reject the idea and state that Carl's Jr better creates another type of ads.

a. Cultural differences between Westerners and Easterners

The cultures between Westerners and Easterners are totally different and most audiences understand this. Some state in their answers that they do not personally like the ads and it makes them feel nauseous, but they try to understand it as it is an ad from overseas. The three women; Putri, Nurul, and Fitri say that it is not a big problem for Carl's Jr to have these kinds of ads as they target the American audiences. Their opinions are as followed:

I do, and do not at the same time, maybe to westerners these kinds of things are of the norm, but here in Asia, showing off one's body excessively is more frown upon. - Putri It depends on the intended audience. Because western cultures are more open and have freedom in appearance, so Carl's Jr. must also pay attention to these differences. - Fitri It shouldn't have been continued because it's not proper to be aired. But it's up to the country where the ads come from. - Nurul

From those statements, they are reluctant to justify the ads yet they cannot protest much because they want to respect the other countries' culture. Personally, they are against the ads as the ads clash with their cultural background and mindset. But, they try to be respectful to other cultures where the ads originate. The three of them think Carl's Jr should continue to produce those ads due to cultural reasons as they think the ads are acceptable in the Westerner audiences' eyes.

Online at https://journal.universitasbumigora.ac.id/index.php/humanitatis/

DOI $\quad$ : https://doi.org/10.30812/humanitatis.v8i1.1427 
b. Proposing Carl's Jr to create public-friendly ads

Although the audiences here understand the producers' intention, they still think the ads should not be continued. A number of audiences suggest Carl's Jr to change their ads' concept for specific reasons such as promoting their products to the younger audiences and people will get bored after watching similar ads continuously. These are some answers that the audiences give when asked "Should the ads continue to be produced?"

No. Since Carl's Jr's consumers are not only coming from the adult. I think they should change the concept of their promotion ads to be more cheerful and friendly. - Alma

I can say no since the viewers are not only adults but kids too. - Diandra

I think they should try creating another kind of ads because people would actually find it boring after sometimes and other products would come up with more brilliant ads Merry

It will be better if they change the concept. The audience will be bored if the ad is the same. - Debby

From those answers, the audiences all disagree with the ads' concept as it is too vulgar for underage children and inappropriate for those young kids to see. A few also suggests Carl's Jr to create other types of ads in order to avoid people's boredom with the ads. Additionally, one of the audiences, Riki gives another piece of advice to Carl's Jr ads producer which is creating ads with other good topics like diversity and body positivity. He thinks there is only one race in the ads which is Caucasian and one type of body type, slim but curvy. He wants to see other races and other body types in the ads to make it more realistic.

\subsubsection{Oppositional Reading}

Unlike people who get negotiated reading, the people in this section misunderstood the real intention of the producer, which is grabbing the customers' interest by using women's bodies as a commodity to promote the product. They also disagree with the producer's views and think the ads do not deserve to be continued. There are two main reasons for that opinion based on the audiences' answers, the ads only work to attract male customers and it is bad to objectify women.

a. The ads will turn off female customers

Several people think that the producer only focuses on male customers since the ads are showing sexy girls with revealing clothes. They think that the ads will turn off female customers

Online at https://journal.universitasbumigora.ac.id/index.php/humanitatis/

DOI $\quad$ : https://doi.org/10.30812/humanitatis.v8i1.1427 
and Carl's Jr might lose female customers' favor if they continue to produce these kinds of ads. Here are some of the answers when asked, "Should the ads continue to be produced?"

No. Because they need to aim females and children who have a bigger chance to shopping and eating - Felicia

Again, it's yes and no. It's about the reception the ads receiving, it could attract male customers, yes but also could damage the image of the restaurant itself. - Karina

No. Because if Carl's Jr continues to produce the ads, their sales will decrease because they lack women's customers. - Arni

With those arguments, three people think it is better to stop rather than taking a risk because women customers might feel uncomfortable by the ads and boycott Carl's Jr product. And this argument is actually backed up by Gramazio's research. In his article, one of Gramazio's findings is women displayed lower consumer responses toward ads that portray women objectification and they also show negative emotion to the ads (Gramazio, Cadinu, Guizzo, \& Carnaghi, 2020). Therefore, the audiences here have good reasons why they want Carl's Jr to stop producing the ads.

b. Age restriction and objectification of women

The majority of audiences have similar opinions; they think the ads are unsuitable to be aired due to their vulgar content. Some voice their worry that children have access to these ads, some argue that harassment towards women will increase if people keep watching those ads.

It's not appropriate for food commercials to focus on women objectification because the women are used to grab customers' attention. These kinds of ads will only increase men's tendency to harass women. - Silvia

Carl's Jr should not continue those ads if they want to be popular with two genders. Carl's Jr should be able to create ads that can target all customers, from children to adults, friendly to all ages and genders, if they want their product to be popular. If their goals are to introduce their product and popularize them, they must be able to make all people, regardless of age, love the product. That is why, choosing the right concept for ads is important. - Wido

No, it should not be continued because Carl's Jr seems to focus much on the meat which they relate to sexual sensation. This is also proven by the women's dresses. They can't use these ads for a long time because it is limited for 21+. The target market is not only $21+$. That's why they should make another strategy. - Revan

I'm feeling inconvenience and irritated because they used women's bodies to promote their product. Maybe they should think about other concepts instead of using women's bodies to sell their product - Luci

Online at https://journal.universitasbumigora.ac.id/index.php/humanitatis/

DOI : https://doi.org/10.30812/humanitatis.v8i1.1427 
No! If they feel proud of their delicious food, they do not need to show those sexy women to attract their consumers. I disagree with the way the ads project women's identity in a vulgar way (big boobs, abs, sweats, really short dress, etc). Women are not objects. Women should be honored by other since woman takes a huge role as a mother of their children. I think the way those ads project women indicates that women's value is disrespected by others. If Carl's Jr really respects women, they will not project women in this way. Maybe they can ask those women to wear proper and polite clothes. - Maria Rather than showing women objectification, it is better to produce ads that highlight the food, for example showing the cooking process of the product. That will attract the customers to buy the product. - Keisya

Those are some protests from the audiences regarding the content of the ads. It seems that many of the Indonesian youngsters' audiences are quite familiar with women objectification and they reject the thought of it as objectification leads to several negative effects for women. One of the effects of objectification is self-objectification which can lead to having low self-esteem, eating depression and depression, or even worse, sexualizing young children (Calogero, 2012). Most of these audiences have a certain awareness of this issue, hence why they want the ads to be stopped.

\section{CONCLUSION}

This paper has explored the objectification of women's bodies in five chosen Carl's Jr ads. The Indonesian youth audiences' opinion on women objectification and their reactions are the focal points of this study. The application of Frederickson \& Barbara's (1997) theory in the study of the ads has provided a chance to explore some of the dimensions of the theory itself along with the chance to study the youth audiences' reception to the women objectification in the media. The Indonesian youngster's audiences' receptions of the ads differ according to their cultural background, age, status, and personal belief.

The study has shown that youngsters noticed the producers' intention behind the ads and support their ideas. But more than half of the youngsters want the ads to be stopped from airing with different reasoning. Some of them despise the ads due to the objectification of women, some of them dislike it because it goes against their morality, and the rest just feel uncomfortable with the ads. Those 28 people noticed that the producers are using the women in the ads to create a buzz so people will talk about Carl's Jr and thus, promoting their product at the same time.

Online at https://journal.universitasbumigora.ac.id/index.php/humanitatis/

DOI : https://doi.org/10.30812/humanitatis.v8i1.1427 


\section{REFERENCES}

Aubrey, J. S., \& Frisby, C. M. (2011). Sexual objectification in music videos: A content analysis comparing gender and genre. Mass Communication and Society, 14(4), 475-501. https://doi.org/10.1080/15205436.2010.513468

Calogero, R. M. (2012). Objectification theory, self-objectification, and body image. In Encyclopedia of Body Image and Human Appearance (Vol. 2). https://doi.org/10.1016/B978-0-12-384925-0.00091-2

Carl's Jr. (2010). Kim Kardashian Carl's Jr Commercial [Television commercial]. Retrieved from https://www.youtube.com/watch?v=DzmFrcuwuuo

Carl's Jr. (2012). Super Bowl Ad : Kate Upton Carl's Jr Commercial [Television commercial]. Retrieved from https://youtu.be/BpWlYZzJ9iY

Carl's Jr. BBQ Best Pair (2012). Ti [Television commercial]. Retrieved from https://youtu.be/hKAeiftUCbw

Carl's Jr. (2015). The All Natural Burger [Television commercial]. Retrieved from https://www.youtube.com/watch?v=WlUvQkW4B1k\&feature=youtu.be

Carl's Jr. (2016). Bacon 3-Way Burger "Fantasy" [Television commercial]. Retrieved from https://www.youtube.com/watch?v=xpWMU01UmR8\&feature=youtu.be

Davis, S. E. (2018). Objectification, Sexualization, and Misrepresentation: Social Media and the College Experience. Social Media and Society, 4(3). https://doi.org/10.1177/2056305118786727

Elinwa, O. J. (2020). Audience Readings and Meaning Negotiation in the Film Viewing Space: An Ethnographic Study of Nollywood's Viewing Center Audiences. SAGE Open, 10(3). https://doi.org/10.1177/2158244020939537

Espiritu, B. F. (2011). Transnational audience reception as a theater of struggle: young Filipino women's reception of Korean television dramas. Asian Journal of Communication, 21(4), 355-372. https://doi.org/10.1080/01292986.2011.580852

Fredrickson, B. L., \& Roberts, T. A. (1997). Toward understanding women's lived experiences and mental health risks. Psychology of Women Quarterly, 21(2), 173-206. https://doi.org/10.1111/j.1471-6402.1997.tb00108.x

Gramazio, S., Cadinu, M., Guizzo, F., \& Carnaghi, A. (2020). Does Sex Really Sell? Paradoxical Effects of Sexualization in Advertising on Product Attractiveness and Purchase Intentions. Sex Roles, (2018). https://doi.org/10.1007/s11199-020-01190-6

Grogan, S. (1999). Body image: Understanding body dissatisfaction in men, women and children, third edition. In Body Image: Understanding Body Dissatisfaction in Men, Women and Children, Third Edition. https://doi.org/10.4324/9781315681528

Hall, S. (1973). Encoding and decoding in the television discourse. Stencilled occasional paper. Training In The Critical Reading of Televisual Language, (September).

Kilbourne, Jean. Killing Us Softly 4. Directed by Sut Jhally, 2010. Media Education Foundation. https://shop.mediaed.org/killing-us-softly-4-p47.aspx

Lennon, S. J., Zheng, Z., \& Fatnassi, A. (2016). Women's revealing Halloween costumes: otherobjectification and sexualization. Fashion and Textiles, 3(1). https://doi.org/10.1186/s40691-016-

Online at https://journal.universitasbumigora.ac.id/index.php/humanitatis/

DOI : https://doi.org/10.30812/humanitatis.v8i1.1427 


\section{3-X}

Rector, J. M. (2014). The Objectification Spectrum: Understanding and Transcending Our Diminishment and Dehumanization of Others. In Oxford University Press.

Schrøder, K. C. (2019). Audience Reception Research in a Post-broadcasting Digital Age. Television and New Media, 20(2), 155-169. https://doi.org/10.1177/1527476418811114

Stewart, K. (2015). Establishing the female gaze: narrative subversion in Lucrecia Martel's La niña santa (2004) and La ciénaga (2001) . Journal of Iberian and Latin American Studies, 21(3), 205-219. https://doi.org/10.1080/14701847.2015.1179850

Szymanski, D. M., Moffitt, L. B., \& Carr, E. R. (2011). Sexual Objectification of Women: Advances to Theory and Research 1 1 7. The Counseling Psychologist, 39(1), 6-38. https://doi.org/10.1177/0011000010378402

Vance, K., Sutter, M., Perrin, P. B., \& Heesacker, M. (2015). Research on perceptions of rape: The medias sexual objectification of women, rape myth acceptance, and interpersonal violence. Journal of Aggression, Maltreatment and Trauma, 24(5), 569-587. https://doi.org/10.1080/10926771.2015.1029179

Yoo, E. E., \& Buzinde, C. N. (2012). Gazing upon the kingdom. An Audience Reception Analysis of a Televised Travelogue. Annals of Tourism Research, 39(1), 221-242. https://doi.org/10.1016/j.annals.2011.06.002 
Online at https://journal.universitasbumigora.ac.id/index.php/humanitatis/

DOI : https://doi.org/10.30812/humanitatis.v8i1.1427 